\title{
MONASTIC SPIRITUALITY IN THE TEACHING OF SAINT BASIL THE GREAT
}

\author{
Ph.D. Candidate Sorin Cristian NUCĂ, \\ "Ovidius" University of Constanta, Constanta, \\ ROMANIA, \\ Email: casiantom@gmail.com
}

\begin{abstract}
The spiritual training of the exceptional beacon of the Cappadocian Fathers, Saint Basil the Great, influenced the subsequent ecclesial life, but especially the monastic one, by the divinely inspired rules, which became essential for all the subsequent monastic settlements, the fruits of the monastic spirituality according to his teaching being substantiated in the principles governing the life of the monastic community by love, obedience, teaching, knowledge, asceticism, without despising the hermitic (skete) life, trying to combine the most useful principles of both of these forms of monastic asceticism.
\end{abstract}

Keywords: spirituality; monasticism; monastic community (chinovie); asceticism; skete;

\section{INTRODUCTION}

The great beacon of the early Church, Saint Basil the Great ${ }^{1}$, a spirit with celestial

\footnotetext{
${ }^{1}$ Information on Saint Basil the Great's life can be found in the most important source Cuvintul 43 (Sermon 43) of Saint Gregory of Nazianzus in vol. Viețile Sfinților (The Lives of the Saints), for the month of January, reprinted and completed with the approval of the Holy Synod of the Romanian Orthodox Church after the edition of 1901-1911, second edition, Publishing House of the Episcopate of Roman (Editura Episcopiei Romanului), 2001, p. 14, unfortunately this edition is altered, some paragraphs being absent, yet it is the only one accessible.

Pieces of news about Saint Basil the Great's life can be found as well in his own writings and especially in his letters (Scrisorile), 366 in all, in vol. Saint Basil the Great, On the Holy Spirit / Despre Sfântul Duh. Corespondență (Epistole), translation, introduction, indexes and notes by Father Prof. Dr. Constantin Cornițescu and Father Prof. Dr. Teodor Bodogae, PSB 12, Editura Institutului Biblic și de Misiune al Bisericii Ortodoxe Române, 1988, then in:

a) Cuvântul funebru în cinstea Sfântului Vasile (Funeral Discourse in Honour of Saint Basil) uttered in 381 by Saint Gregory of Nazianzus and in vol. Fr. Prof. N. Donos, Sf. Grigore de Nazianz, Apologia sau cuvântarea în care arată motivele care l-au îndemnat să fugă de preoție și Elogiul Sfântului Vasile (Apology or Discourse showing the Reasons that Exhorted him to Run Away from Priesthood and Eulogy to Saint Basil), Huși, 1931, p. 118-204, Cuvîntul 43 (Discourse 43), PG., 36, p. 493-608;

b) Cuvântul funebru (Funeral Discourse) uttered by his brother, Saint Gregory of Nyssa in PG, 46, p. 787-818;

c) Viața cuvioasei Macrina (The Life of Saint Macrina) by Saint Gregory of Nyssa in PG, 46, 959-1000, translated in Romanian by Fr. Prof. Dr. Teodor Bodogae, Sibiu, 1947;

d) Cuvântul Sfântului Efrem Sirul (Discourse of Saint Ephrem the Syrian), according to some pseudo-Ephrem in S. P. N. Ephraem Syri Opera omnia quae existant graece, latine, syriace in sex tomos distributa, Roma e Bibliotheca Vaticana prodeunt, Tomus 2, Romae, 1743, p. 289-296;

e) Viața Sfântului Vasile cel Mare (The Life of Saint Basil the Great), attributed to his friend (cousin) Saint Amphilochius of Iconia, is a work written in the eighth century in Greek and Latin at F. Combefis, SS. Patrum Amphilochii Iconiensis, Methodii Patarensis et Andreae Cretensis opp., Paris, 1644, 155-225; only in Latin, in PG, 29, CCXCIV-CCCXVI;
} 
lights, is the personality standing out among the bright precious stones of the golden age of the Church. He had a fruitful activity in almost all the ecclesial domains in his time, such as: dogmatic, moral, homiletic, pastoral-missionary, liturgical, canonical, caritative-social and, naturally, in the ascetic-monastic domain.

The spiritual training of the most prominent of the Cappadocian Fathers stands out by the saint's preparation in order to vitalize the monastic spiritual life since his epoch to this day, influencing, for example, the Athonite monastic life, by three factors: family, Church and school, recognized as well by the modern science of psycho-pedagogy as: genetic heritage (family tree), environment and education ${ }^{2}$.

Regarding the genealogical tree ${ }^{3}$ (Exodus 20:5-6) of Saint Basil the Great, it reconfirmed the proverb: If the root is holy, so are the branches (Romans 11:16). Indeed both on his father's side, and of his mother's side, the spiritual heritage was exceptional, his grandmother Macrina the Elder being holy and a disciple of Saint Gregory Thaumaturgus (the Miracle-Worker), and his mother, Saint Emilia, a martyr's daughter. Out of the ten children of Saint Basil's family, four are saints: himself, Saint Gregory of Nyssa, Saint Peter of Sebaste the Bishop and Saint Macrina the Young.

While his mother Emilia and Macrina the Elder had instilled in him the holy teachings, as they had received them from the tradition of the Church, his father, Basil ${ }^{4}$, was a famous rhetor, and initiated his son in sciences. He followed, after the education started in the family, the best known schools of his time at Caesarea in Cappadocia, at Constantinople and in Athens, where he will acquire a special friend, Saint Gregory the Theologian. Studying all the sciences of his time, Basil returned to his country and taught rhetoric. Following the example of his sister Macrina, whose fiancé had died, he decided to dedicate himself to the ecclesial mission, received baptism and entered monasticism.

He showed a science much higher than the ordinary for people of his age and a strength of mores even much higher than his science. ${ }^{5}$

There are apparently also experts who saw in the affirmation of Saint Gregory the Theologian that [Saint Basil] was priest among the Christians, even before having received the gift of priesthood, just rhetorical exaggeration, but in fact only universal priesthood has an eternal value, the other (hierarchical priesthood) risking being generally undoubtedly doomed .

The region in which Saint Basil the Great, Cappadocia, has a tumultuous history,

f) Finally, in the Church historians: Jerome, De Viris Illustribus, 116, Socrate, Istoria Bisericească (Church History), IV, 26, Sozomen, Istoria Bisericească (Church History), VI, 1.5-17, Teodoret, Istoria Bisericească (Church History)(, IV, 19. 30, Filostorgiu, Istoria Bisericească (Church History ), II, 9, and also in Biblioteca lui Fotie, Cod. 137. 141-144. 191.

${ }^{2}$ Cucoș Constantin, Educația religioasă (Religious education), Polirom Publishing House, Iași, 1999, p. 26.

${ }^{3}$ Dr. Kenneth McAll, Vindecarea arborelui genealogic (Healing the family tree), Harisma Publishing House, Bucharest, p. 47.

${ }^{4}$ Pontus, says Saint Gregory the Theologian, considered Basil the rhetor as a teacher for everybody of the good teachings and acts, during that time, in vol. Viețile Sfinților (The Lives of the Saints), for the month of January, p. 14 or in vol. Pr. Prof. N. Donos, Sf. Grigore de Nazianz, Apologia sau cuvîntarea în care arată motivele care l-au îndemnat să fugă de preoție și Elogiul sfintului Vasile (St. Gregory of Nazianzus, the Apology or speech in which he shows the reasons that prompted him to flee the priesthood and the Praise of St. Basil), Huși, 1931, p. 129, Cuvintul 43, PG., 36, p. 493-608.

${ }^{5}$ Viețile Sfinților (The Lives of the Saints), for the month of January, p. 15 or in vol. Pr. Prof. N. Donos, op. cit., p. 131. 
entirely special, in which the Arian ${ }^{6}$ and the Semitic culture, Europe and Asia intertwined.

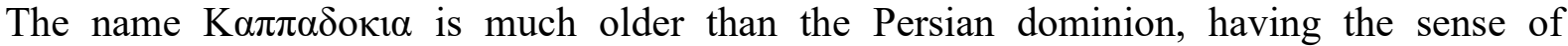
Cap(head, ending) of Dacia or Dochia ${ }^{7}$ (Deciana) (literally in Romanian), most probably the deity of justice and fertility of the earth at the Carpathians, Danube and the Black Sea. Specialists draw our attention to the fact that during the second sophistic age of the great Christian writers of Cappadocia "the Aramaic continued to be lingua franca in numerous areas ${ }^{8}$ of Cappadocia and in its surrounding areas, even thousands of kilometers away".

What is amazing linguistically, at least, and this is something I understood much better due to the experience in the Holy Mount Athos, is the fact that at least $50 \%$ of the words met in the Cappadocian Fathers' original text (in Old Greek or more correctly said of Aromanian or Macedonian language) have sense in today's Romanian, which demonstrate a continuity of over 2000 years of this language, whose representatives can rightly be considered a diaspora of the waves of Arians whose family tree root is according to all the evidence Carpathian-Danubian-Pontic, which is why throughout the work, whenever there are going to be theological implications of certain words borrowed by the Greek from the Aromanian language of the Wallachian-Dacian-Gethians and it will be a must to clarify these meanings, we will signal it.

The years spent by Basil the Great for the training by studies had become years of a spirtual, inner deformation (approx. 342-357), the lay environment had left its mark by the spirits of the world (vain glory, self importance) on the blessed heritage of the childhood whch he had received thanks to his grandmother Macrina, of his mother Emilia and he was aware of it fully, extremely painfully, as a void that rips apart and that nothing else can fill.

\section{THE MONACHAL LIFE OF SAINT VASILE THE GREAT AND THE MONASTERIES FOUNDED BY HIM}

"Before the greatness of the Church's own way of life, the morality of the people he had met in Caesarea, Constantinople, and Athena was a baseness, a perversion" ${ }^{10}$. After the death of his father, attracted to monasticism, Saint Basil the Great decided to leave the world. Looking for a mentor, he initially found him in the person of Eustatius, a rigorous ascetic who had previously studied in Alexandria. From the church historian Sozomen [Church History III, 14; IV, 27 n.n.] we find that Eustatius (300-377; bishop of Sevastia 357/358 ${ }^{11}$ ) has the merit of being a beginner of monasticism in Asia Minor (Armenia, Paphlagonia,

\footnotetext{
${ }^{6}$ Nicolae Densușianu, Dacia Preistorică (Prehistoric Dacia), Arhetip Publishing House, București, 2002, p. 680(n. 13), p. 803. Petre Morar, Dacia Ariană (Arian Dacia),https://www.academia.edu/4625746/Petre_Morar_Dacia_Ariana, cap.II.7 p. 2 (Românii hitiți și Egiptul Antic/ Hittite Romanians and Ancient Egypt ).

${ }^{7}$ Dr. Lucian Iosif Cueșdean, Româna, Limba Vechii Europe, (Romanian, The Language of Old Europe), Editura Solif, București, 2006, p. 59; George Cadar, Ardahal, Despre originea, limba și mitologia vlaho-daco-geților (Ardahal, about the origin, language and mythology of the Vlach-Daco-Getae), Proema Publishing House, Baia Mare, 2019, p. 29.

${ }^{8}$ Pr. Dr. Liviu Petcu, Îndumnezeirea omului după învățătura Sfântului Grigorie de Nyssa (The deification of man according to the teaching of St. Gregory of Nyssa) Astra Museum Publishing House, Sibiu, 2013, p. 34.

${ }^{9}$ Pr. Prof. Univ. Dr. Nicolae Achimescu, Istoria și Filosofia Religiilor. Religii ale Lumii Antice (History and Philosophy of Religions. Religions of the Ancient World), Basilica Publishing House, Bucharest, 2015, p. 178, 210, 236; Gabriel Gheorghe, Valah, Editura Fundației Gândirea, București, 2012, p. 7-10.

${ }^{10}$ Stelianos Papadopoulos, Viața Sfântului Vasile cel Mare (The life of Saint Basil the Great), Bizantină Publishing House, Bucharest, 2003, p. 62.

${ }^{11}$ Ibidem, p. 81.
} 
Pontus and Cappadocia, but also in Constantinople) in an organized form. ${ }^{12}$ We also learn that the old ascetic, aged with the parents of St. Basil the Great, promoted an apostolic, philanthropic and social spiritual life in the city, but aroused from the beginning the distrust of the clergy as his asceticism imposed celibacy and total poverty as ideal conditions of Christian life, isolating themselves from the parishes and the cult celebrated by married priests. Eustatius minimized the ritual aspect, and his asceticism was intended as a movement of harsimatic renewal of the institutionalized Church. Unfortunately, these deviations from the spiritual life led to doctrinal slippages reflected in his unity of vision with Macedonie of Constantinople, which consisted primarily in a moderate Semiarianism (common throughout Asia Minor).

Although, on the background of a rivalry between Eusebius of Caesarea, Cappadocia (future Bishop of Nicomedia) and Macedonius of Constantinople, the Synod of Gangra (in Paphlagonia, 340-341), condamned the ascetic "Eustatian" movement in 20 canons for the fact of representing a destabilizing factor for the official church. ${ }^{13}$

Coming from a family of martyrs and knowing an improvised, yet sincere monastic practice (through his mother and sister Macrina), Saint Basil had the occasion to know the monastic way of life promoted by Eustatius, yet discontent by its results, he turned his attention to the dedicated monastic centres of the East, respectively from the Holy Land. In Epistle 223, 2 he mentions that he visited Syria, Palestine and Mesopotamia where he met hermits. ${ }^{14}$ At the same time, he also went to Egypt, out of the desire to meet Saint Athanasius the Great (around 295-373), "the pillar of the Orthodoxy" at the First Ecumenical Council, disciple of Anthony the Great $(\dagger 356)$, who was however in exile at that time in the zones hard to access of Thebaid, inaccessible to Basil the Great.

Although he did not have the chance to know personally the respresentatives of the monasticism of Egypt, Anthony and Pachomius the Great, who had passed into enternity, Saint Basil the Great knew, however, the Pachomian monasticism in the person of the different monks met during the pilgrimage through Egypt, where he actually stayed for a few whole months (the whole spring, the summer and a part of the autumn of $357^{15}$ ). The teaching of the desert left an undeletable, unique mark on him, characterized by visitations of the divine grace, but also by moments of the persecution initiated by the Arians against the Orthodox clerics who were persecuted, mocked, thrown out on the roads naked, half dead, becoming some of them confessors of the faith. ${ }^{16}$

On the way back, he also wanted to meet the ascetics of Palestine and Syria. Thus, he passed through Gaza, where Avva Ilarion had been needed for some time, an example of combining monasticism with missionary work, whose disciples he could meet in person. At Caesarea in Palestine he saw again the city where Origen had lived for a time, the teacher of

\footnotetext{
${ }^{12}$ Cf. J. Gribomont, Dictionnaire de Spiritualité IV/2 (1961), col. 1708-1712; Diac. Ioan Ică jr., „The Vigilent Ones - Eastern Apostolic Monasticism: The Destiny and Metamorphoses of a Forgotten Charism "in ***, The Breviary and the Lives of the Vigilent Monks, translation and afterword by the deacon Ioan Ică jr., Deisis Publishing House, Sibiu, 2006, p. 238.

${ }^{13}$ Diac. Ioan Ică jr., „,The Vigilant Ones...”, p. 240.

${ }^{14}$ Saint Basil the Great, Writings. Part III, translation, introduction, notes and indexes by Priest Prof. Dr. Constantin Cornițescu and Priest Prof. Dr. Teodor Bodogae, col. „P.S.B.”, vol. 12, I.B.M.B.O.R. Publishing House, București, 1989, p. 458.

${ }^{15}$ Ibidem.

${ }^{16}$ Saint Athanasius the Great, Writings, Part II, Epistles, The Life of Our Reverend Father Anthony, col. PSB 16, transl., introd. and notes by Pr. Dumitru Stăniloae, Publishing House of the Biblical and Mission Institute of the Romanian Orthodox Church, Bucharest, 1988, p. 219.
} 


\section{International Journal of Theology, Philosophy and Science \\ No. 9, Year 5/2021 \\ https://ijtps.com/ \\ ISSN 2601-1697, ISSN-L 2601-1689}

St. Gregory the Thaumaturgist, the spiritual father of Macrina the Elder, the grandmother of St. Basil the Great. ${ }^{17}$ The return route also included the fortress of Antiochia and the area between the Tigris and Euphrates, populated by monks.

Elucidated about the path he had to follow, returned to Caesarea in Cappadocia in the late autumn of 357, St. Basil the Great gladly finds the old bishop Dianiu of Caesarea, who baptized him on this occasion (358). After taking this step, he also decided on the division of the wealth he felt as a burden, incompatible with monastic life.

We can say that in the winter of 358 he retired to the property he had left in Anissa, in order to need himself as a monk after the model seen in the East, responding on this occasion to Bishop Eustatius' request to make rules to improve the lives of his monks. He may have used the notes he had made during his trip to the East, remembering the virtues and needs of the ascetics ${ }^{18}$ there. Although he had not yet reached the age of 30 , he managed to concretize his native-spiritual gift and the experience gained, by writing and, later, completing what would become the spiritual code of Christian monasticism. ${ }^{19}$

At Anissa he did not forget his friend Gregory, whom he invited to work together after his consent during his studies at Athena, through an epistle in which he also presents a guide to the life of an ascetic chinovia. The principles were very harsh, specific to youthful zeal, but he would later revise them, moving the ascetic community to the city and giving it a philanthropic character.

Summarizing this guide of Saint Basil the Great, we further present its main elements: the peace of mind, the research of the Holy Scriptures, the prayer program.

The "peace of mind" is rightly considered the eye of the soul ${ }^{20}$, the beginning of cleansing $^{21}$ is achieved by giving up worldly worries ${ }^{22}$ and leaving off bad habits. ${ }^{23}$

The Holy Scriptures ${ }^{24}$, sources of divine teaching ${ }^{25}$, mediate the habit of godliness ${ }^{26}$, the nourishment of the soul ${ }^{27}$. From their constant study one reaches the discovery of the saving truth in response to the problems of the Christian life. ${ }^{28}$

It can be seen in this epistle, the overwhelming weight of a day that St. Basil the Great

\footnotetext{
${ }^{17}$ Stelianos Papadopoulos, The Life of Saint Basil the Great..., p. 72-73.

18 . The word comes from the archaic Romanian verb "to sharpen"/a ascuti - asceticism ( $\alpha \sigma \kappa \eta \sigma \eta)$ and has as its spiritual meaning the stringing of all the senses and the attention that must be sharpened in order to penetrate the mysteries, like the cherubs with many eyes. Hence the word ski/schi $(u) t(\sigma \kappa \eta \tau \eta)$, so used in monasticism, originating from the shield. It is no coincidence that the old name of Dobrogea is Sci (u) thia Minor. Just as the shield is used as a defense in battle (war), the hermitage/skete is a defense against the lust of the eyes, the body, and the pride of life (I John 2:16). Both are part of the same lexical family which only in Romanian is so complete and rich, later being borrowed like many other words in Greek. In ancient times (about 2000 years BC) the whole of Asia was called Scithia, as we can see on ancient maps.

19 As main monastic writings, we mention: Moral Rules (80), Great Rules (55), Small Rules (318), Ascetic Constitutions and ascetic canons and epistles.

${ }^{20}$ Saint Basil the Great, Writings. Part III, Epistle 2, II, p. 117. See for quotations from this epistle and the translation from col. „PSB”, vol. 18, I.B.M.B.O.R. Publishing House, Bucharest, 1989, p. 531-536.

${ }^{21}$ Saint Basil the Great, Writings. Part III, Epistle 2, II, p. 119.

${ }^{22}$ Saint Basil the Great, Writings. Part III, Epistle 2, II, p. 118.

${ }^{23}$ Saint Basil the Great, Writings. Part III, Epistle 2, II, p. 118.

${ }^{24}$ Saint Basil the Great, Writings. Part III, Epistle 2, II, III, p. 119.

${ }^{25}$ Saint Basil the Great, Writings. Part III, Epistle 2, II, p. 118.

${ }^{26}$ Saint Basil the Great, Writings. Part III, Epistle 2, II, p. 119.

${ }^{27}$ Saint Basil the Great, Writings. Part III, Epistle 2, II, p. 119.

${ }^{28}$ Saint Basil the Great uses the parables of the lives of the righteous of the Old Testament as a model to follow in the Christian or monastic life. "For example, one who loves virginity often reads the story of Joseph, learning from his deeds how to keep himself clean."
} 
gives to the soul, in contrast to the concern for bodily needs, reserving an hour for the latter, but 23 hours for the soul. ${ }^{29}$ Prayer, all the time, day and night, receives a special place, in order to acquire a quality in which the presence of God becomes constant: "For it is the good prayer that makes a clear conception of God take root in the soul, and the abode of God in us consists precisely in having God firmly in mind. Only then do we become temples of the Spirit, when the steadfast thought of Him is no longer interrupted by earthly cares, and when the mind is not disturbed by fleeting passions. " 30 The rest of the body becomes, in his opinion, something secondary, a necessity of the fallen nature, but it is subject to rules which are intended not to hinder the faith of the believer from the great troubles of salvation. ${ }^{31}$ Replacing sleep with vigilance and vigilance is a face of the resurrection of the soul that provides the perception of God's presence. The nocturnal peace, says Saint Basil the Great, "rests the soul", that is, protects it from passions and intensifies its power to do good (virtue), if it is accompanied by the recognition of sins, the will to correct and summon the divine help. ${ }^{32}$

The activity of Saint Basil the Great "was not limited only to the founding of this monastery in Pontus. It was just like a model, a guide after which he founded many other places as a place for monastic associations. This results even from Rule 54 as well as from the testimonies of the historians Rufin and Sozomen." ${ }^{33}$ By this rule, it was decided that at certain places or times, the heads of the monastic communities should analyze the difficult moral problems and give solutions by judging several.

\section{THE ORDER OF MONASTIC LIFE}

At the call of Bishop Dianius to come to Caesarea in Cappadocia, he leaves the monastery on the river Iris and is appointed after the ordination to the priest, preacher at the Diocesan Center out of the need to respond to the intensified challenges of the Aryans. Saint Basil the Great will fulfill this obedience until the sleep of Dianius, followed on the throne by Eusebius, when he returns to Pontus ${ }^{34}$, resuming his ascesis with his friend Gregory. In Anissia, the two theologians will compile, in addition to the philocal anthology of Origen's works, the two ascetic treatises that comprise the principles of public life: The great and the small rules. It is believed that Saint Basil used in the writing of the text some of the rules / regulations for organizing the older monasteries in the East, especially in $\mathrm{Egypt}^{35}$ (probably the Pachomian or Tabenite Chinovites ${ }^{36}$ ).

Comparing the ordinances of St. Basil with those of St. Anthony and Pachomius, there is a resemblance in substance and, often, in form. The order of Saint Basil differs from the older ones, deepening the spiritual part and less the external one. "All his ordinances are based on reason and sometimes seem to be the simple fruit of his sharp mind and not the fruit of the skill gained through life, through daily experience."37

\footnotetext{
${ }^{29}$ Saint Basil the Great, Writings. Part III, Epistle 2, VI, p. 122.

${ }^{30}$ Saint Basil the Great, Writings. Part III, Epistle 2, IV, p. 120.

${ }^{31}$ Saint Basil the Great, Writings. Part III, Epistle 2, VI, p. 122.

${ }^{32}$ Saint Basil the Great, Writings. Part III, Epistle 2, p. 122-123.

${ }^{33}$ Archdeacon Ioan N. Floca, "Saint Basil the Great, reorganizer of monastic life", in vol. Studia Basiliana I, worship at 1630 years, second edition revised, added and edited by Emilian Popescu and Adrian Marinescu, Basilica Publishing House Of the Romanian Patriarchate, Bucharest, 2009, p. 504.

${ }^{34}$ See Epistle 8, vol. St. Basil the Great, Writings. Part III, p. 130-141.

${ }^{35}$ See Epistle 23, vol. St. Basil the Great, Writings. Part III, p. 159.

${ }^{36}$ See Epistle 23, vol. St. Basil the Great, Writings. Part III p. 159.

${ }^{37}$ Archdeacon Ioan N. Floca, "Saint Basil the Great, reorganizer...", p. 506.
} 
Saint Basil the Great teaches that in order to live perfectly according to the evangelical law, it is necessary to give up the world. There are many kinds of life that involve worldly renunciation, but people have been forced in all these ways and they can lead to the purpose of the Christian life: salvation, holiness. "Saint Basil finds that the most appropriate kind of life rejected by the world is the monastic one, so-called idiorhythmic, when, living in the same monastery, the monks lead a life locked in their cells and this as opposed to the anchoretic, lonely life, not the one led by the disciples of St. Anthony, but the one that St. Basil saw in his places, the lonely life without supervision and guidance, in which you cannot escape the connections with the world and the laity.

Such a solitary life did not lead straight to the target and was bound by too many difficulties, although it is above the public life. St. Basil placed this kind of monasticism in which he wanted to gather all that is best in the lonely ascetic life and to remove all that he found in it unsuitable for reaching the goal. And the monastic life he founded was lonely, but trapped in a trunk, where everyone could feel as if they were alone." 38

\section{PRINCIPLES OF ORGANIZATION AND FUNCTIONING OF MONASTIC LIFE}

Among the fundamental principles of the inner (inner) life, Saint Basil establishes the following:

a) The principle of love or love for God and people;

b) The principle of voluntary renunciation or poverty;

c) The principle of asceticism, restraint, self-denial or virginity;

d) The principle of isolation, living alone with respect to housing;

e) The principle of living in communion with those who have the same goal, having everything in common; chinovia;

f) The principle of unconditional obedience to the superior of the community /

g) The principle of combining the research of Holy Scripture and prayer with work;

h) The obligation to take the Eucharist as often as possible, daily if possible, as a sign of communion.

He based all these on the teaching of Holy Scripture, showing their practical value and how they were carried out by the followers of the Lord's commandments and how they can be applied in the community in which they live. ${ }^{39}$

There are also principles (norms) that regulate the external aspects of the organization of monastic life: the rules or norms of living refer to: a) the way of organization; b) leadership and administration of monastic life; c) upon receipt in the monastic society; d) the behavior of the monks; e) internal and external relations; f) goods administration; g) training of disciples, h) unitary organization (monastic discipline); i) monastic justice; j) patient care; k) leaving the framework of the monastic / monastic society etc. ${ }^{40}$

\section{THE TARGET / PURPOSE / FRUITS OF MONASTIC LIFE}

"If the source and essence of spirituality is the Holy Spirit of God, the area over which He pours out abundantly, working and bearing fruit to perfection, is the very being of the believer. This creates a natural connection between the source and the entire course of the

\footnotetext{
${ }^{38}$ Teofan Zăvorâtul, The rules of monastic life, Sophia Publishing House, Bucharest, 2002, p. 175.

${ }^{39}$ Archdeacon Ioan N. Floca, "Saint Basil the Great, reorganizer of monastic life", p. 510.

${ }^{40}$ Archdeacon Ioan N. Floca, "Saint Basil the Great, reorganizer of monastic life", p. 517.
} 
believer's spiritual life."41

"God's commandments must be fully fulfilled for spiritual advancement, St. Basil says categorically: If it were not necessary for the purpose of salvation, all the commandments would not have been written, nor would the unconditional observance of all have been commanded. $^{42, "}$

"Regarding the spiritual life of the Christian, it can certainly be noticed that it has an immediately achievable object here, by perfecting the personality of the Christian, the other objective being in the perspective of acquiring the kingdom of heaven. Between the two objectives there must be the correlation that a Christian spirituality demands through the virtuous transition from a form of living, always to a higher one, from the being of the old man to the new one. "(Col. 3, 9-10).

This change for the better as a guarantee of the perfection of human nature (Homily in Psalm $44^{43}$ ), is itself a path to heaven, the way to heaven, and the transformation of corruption into incorruption, the gain of true spiritual treasures, and the tasting of God's goodness. $33^{44}$ ).

All this, as well as other benefits, means communion with God, friendship and living in Him. He who has the steadfastness and unchangeability of that friendship in Christ, ... only the perfect can truly know the beloved ${ }^{45}$. Or the same is shown: So, on the one hand, the real life is Christ, and on the other hand, our living in Him is the true life. . ${ }^{46}$

An essential note of the spiritual work is the very fullness of life, the remembrance of death caused by sin, to life in Jesus Christ. ${ }^{47}$

Saint Basil the Great says: With Your resurrection you gave us to rise from men to God. $^{48}$ Then he says: And it was not enough, that He made us alive from the dead, but also bestowed upon us the dignity of His divinity, and prepared for us the eternal rest, which surpasses in glory and joy all human thought. ${ }^{49}$

It should be noted here the observation of some theologians that, for St. Basil, the notions of perfection or consummation, sanctification and, implicitly, deification are found unified on a higher level where they have their origin, i.e., in the work of the Holy Spirit, the very Holy Trinity. ${ }^{50}$ The fact is also explained by the fact that there is a close connection between the believer's being and his aspiration for perfection. The believer not only reflects in his being a whole spirituality, but himself becomes a valuable factor in its affirmation.

Through the work of holiness, perfection, deification, and the contemplation of the beauty of the archetype, the Holy Spirit makes possible the resumption of the image of God by all who allow themselves to be blossomed by the dew of grace; and as this image is one,

${ }^{41}$ Timotei Seviciu, The spirituality of Saint Basil the Great, in "Saint Basil the Great, reorganizer of monastic life", in vol. Studia Basiliana I, worship at 1630 years, second edition revised, added and cared for by Emilian Popescu and Adrian Marinescu, vol III, Basilica Publishing House of the Romanian Patriarchate, Bucharest, 2009 , p. 313.

${ }^{42}$ Saint Basil the Great, The Great Rules, Prologue II, P.G. XXXI-893B.

${ }^{43}$ P.G. 29, 364D-365A; C, p. 180-181.

${ }^{44}$ P.G. 29, 388A;C, p. 203.

${ }^{45}$ Homily on Psalml 44, P.G. 29, 392 C-D; C, p. 208-209; Moral rules III, 2, P.G. 31, 705 C-D - 708A.

${ }^{46}$ Homily on Psalm 33, P.G. 29, 372 C-D; C, p. 189.

${ }^{47}$ Moral rules III, 2, P.G. 31, 913 C.

${ }^{48}$ Saint Basil the Great, Molitfa II, P.G. 31, 1684A.

${ }^{49}$ The Great Rules II, 4, P.G. 31, 916A.

${ }^{50}$ Benoit Pruche, în vol. Basile de Cesarée, Traité du Saint Esprit, introduction, traduction et notes par Benoit Pruche, OP col. S.Chr. 17, Paris, 1947, p. 94. 
its realization in all is manifested by the union with one, the one and only true God.

The teaching of the Holy Spirit and divine grace is a powerful impetus for the believer in the spiritual ascent to the heights of Christian perfection. The means of traversing the ascent are those that the Church itself puts at hand. Saint Basil envelops everything with the authority of personal experience, the validity of his principles being verified by those who followed his example.

It would seem that his teachings concern more a high level, which could be achieved only by the saints, preferably clergy. Of course, for those who have chosen a certain way of life, the duties are increased, but the other believers are not excluded from these duties either. The essence is the same, the difference lies in the stage of realization of the precepts of the Gospel.

"The spirituality of Saint Basil does not detach from the real plans of life, but concerns, in concrete terms, the elevation of the believer in communion with others by promoting the values and ideals of Christian and human unity. His thinking, enriched by a high experience, is one of the most important contributions to the affirmation of Orthodox spirituality, opening in the hearts the gates of eternal beauty." 51

"The way of life conceived by St. Basil and experienced in the fraternities founded and led by him proved superior, coming from principles based on the reality of monastic life, which imposed them and became widespread taking concrete forms in the various systems experienced from then until today. Today its norms are still the foundation of the organization of monastic life in the whole Church and constitute the main guide regarding the current organization of monasticism within our Church " 52 as those in the Holy Mount Athos are.

\section{CONCLUSION}

The monastic spirituality in the teaching of Saint Basil the Great proves to us that monasticism is a mountain hard to climb, yet for the Christian getting ready as it is fit for this purpose with the gift of the Holy Spirit, by continually pushing the natural limits, one can note progressively that God does not give the Spirit with measure, and without rules (principles) it is not possible to delight in the gifts of the Holy Spirit. This great beacon of the Church and of the whole world obtained these fruits that he shares with all having as fundament the triad: family, Church and school or family tree, environment and education.

\section{BIBLIOGRAPHY:}

[1] ***, The funeral discourse spoken by his brother, St. Gregory of Nice in P.G. 46, pp. 787-818.

[2] ***, The discourse of St. Ephrem the Syrian, according to some pseudo-Ephraim in $S$. $P$. N. Ephraem Syri Opera omnia quae existant graece, latine, syriacein sex tomos distributa, Roma e Bibliotheca Vaticana prodeunt, Tomus 2, Romae, 1743, pp. 289-296.

[3] Achimescu, Nicolae, History and Philosophy of Religions. Religions of the Ancient World, Basilica Publishing House, , Bucharest, 2015.

[4] Saint Athanasius the Great, Writings, Part II, Epistles, The Life of Our Reverend Father Anthony, Col. PSB 16, transl., Introd. and notes by Fr. Dumitru Stăniloae, Publishing House of the Biblical and Mission Institute of the Romanian Orthodox Church, Bucharest,1988;

[5] Cadar, George, Ardahal, About the origin, language and mythology of the Vlach-Daco-Getae, Proema Publishing House, Baia Mare, 2019.

[6] Cucoș, Constantin, Religious education, Polirom Publishing House, Iași, 1999.

[7] Cueșdean, Lucian Iosif, Romanian, Language of Old Europe, Solif Publishing House, Bucharest, 2006.

${ }^{51}$ Timotei Seviciu, The spirituality of Saint Basil the Great..., p. 324-327.

${ }^{52}$ Arhid. Ioan N. Floca, „Saint Basil the Great, reorganizer of monastic life”, p. 520. 
[8] Densușianu, Nicolae, Prehistoric Dacia, Arhetip Publishing House, Bucharest, 2002.

[9] Donoș, N., St. Gregory of Nazianzus, the Apology or speech in which he shows the reasons that prompted him to flee from the priesthood and the Praise of St. Basil, Huși, 1931, pp. 118-204; PG. 36, pp. 493-608;

[10] Filostorgiu, Church History (II, 9), translation by Dorin Garofeanu, introductory study, chronological table, explanatory notes and annexes by Dragoș Mîrșanu, Polirom Publishing House, Iași, 2012.

[11] Floca, Ioan, „Saint Basil the Great, reorganizer of monastic life ”, in vol. Studia Basiliana I, worship at 1630 years, second edition revised, added and edited by Emilian Popescu and Adrian Marinescu, Basilica Publishing House of the Romanian Patriarchate, Bucharest, 2009, pp. 500522.

[12] Gheorghe, Gabriel, Wallachian, Gândirea Foundation Publishing House, Bucharest, 2012;

[13] Ică jr., Ioan, „The Vigilent Ones - Eastern Apostolic Monasticism: The Destiny and Metamorphoses of a Forgotten Charism "in ***, The Breviary and the Lives of the Vigilent Monks, translation and afterword by the deacon Ioan Ică jr., Deisis Publishing House, Sibiu, 2006, pp. 238-246.

[14] Ieronim, De viris ilustribus, 116.

[15] McAll, Kenneth, Healing the family tree, Harisma Publishing House, Bucharest, 1993.

[16] Morar, Petre, Arian Dacia, https://www.academia.edu/4625746/Petre_Morar_Dacia_Ariana.

[17] Papadopoulos, Stelianos, The life of Saint Basil the Great, Byzantine Publishing House, Bucharest, 2003.

[18] Petcu, Liviu, The deification of man according to the teaching of St. Gregory of Nyssa, Astra Museum Publishing House,Sibiu, 2013.

[19] Photius, Bibliotheca or Myriobiblion (Cod. 1-165), translated by John Henry Freese, digitized edition available at http://www.tertullian.org/fathers/photius_03bibliotheca.htm (visit of September 25, 2021).

[20] Basile de Cesarée, Traité du Saint Esprit, introduction, traduction et notes par Benoit Pruche, OP col. ,Sources Chrétiennes”, vol. 17, Paris, 1947.

[21] Seviciu, Timotei, "Saint Basil the Great, reorganizer of monastic life", in vol. Studia Basiliana I, worship at 1630 years, second edition revised, added and edited by Emilian Popescu and Adrian Marinescu, Basilica Publishing House of the Romanian Patriarchate, Bucharest,2009, pp. 305329.

[22] Saint Basil the Great, Writings. Part I, in col. "P.S.B.”, vol. 17, transl. Fr. D. Fecioru, Publishing House of the Biblical and Mission Institute of the Romanian Orthodox Church (I.B.M.B.O.R.), Bucharest, 1986.

[23] Saint Basil the Great, Writings. Part II, in col. "P.S.B.", vol 18, transl. Iorgu D. Ivan, I.B.M.B.O.R. Publishing House, Bucharest, 1989.

[24] Saint Basil the Great, Writings. Part III, in col. „P.S.B.”, vol. 12, translation, introduction, notes and indexes by Priest Prof. Dr. Constantin Corniţescu and Priest Prof. Dr. Teodor Bodogae, I.B.M.B.O.R. Publishing House, Bucharest, 1989.

[25] Saint Gregory the Theologian, "Word 43" in vol The Lives of the Saints, January, reprinted and added with the approval of the Holy Synod of the Romanian Orthodox Church after the 19011911 edition, the second edition, the Episcopia Romanului Publishing House, 2001, pp. 14-44.

[26] Saint Basil the Great, Correspondence (Epistles), trans. Fr. Constantin Corniţescu and Fr. Teodor Bodogae, in: St. Basil the Great, Writings. Part III.Sfântul Vasile cel Mare,

[27] About the Holy Spirit. Correspondence (Epistles), translation, introduction, indexes and notes by Priest Prof. Dr. Constantin Cornițescu and Priest Prof. Dr. Teodor Bodogae, in col. „P.S.B.”, vol. 12, Publishing House of the Biblical and Mission Institute of the Romanian Orthodox Church, Bucharest, 1988.

[28] Saint Basil the Great, About the Holy Spirit, trans. Fr. Constantin Corniţescu and Fr. Teodor Bodogae, in: St. Basil the Great, Writings. Part three, PSB 12, EIB, Bucharest, 1988.

[29] Saint Basil the Great, Molitfa II, P.G. 31, 1684A.

[30] Saint Basil the Great, Homilies to the Psalms, trans. Fr. D. Fecioru in vol. Writings, part I.

[31] Saint Basil the Great, Homilies and speeches, trans. Fr. D. Fecioru in vol. Writings part I.

[32] Saint Basil the Great, The Great Rules, trans. Iorgu D. Ivan, in: St. Basil the Great, Writings, part two, "P.S.B.”, vol. 18, E.I.B.M.B.O.R., Bucharest, 1989. 
[33] Saint Basil the Great, The Little Rules, trans. Iorgu D. Ivan, in: St. Basil the Great, Writings, part two, "P.S.B.", vol. 18, Editura.I.B.M.B.O.R., Bucharest, 1989.

[34] Saint Basil the Great, Writings. Part III, translation, introduction, notes and indexes by Priest Prof. Dr. Constantin Corniţescu and Priest Prof. Dr. Teodor Bodogae, in col. „P.S.B.”, vol. 12, I.B.M.B.O.R. Publishing House, Bucharest, 1989.

[35] Saint Basil the Great, Saint Pachomius the Great, Saint John Casian, Saint Benedict, The Ordinances of the monastic life, a collection composed by Saint Theophanes the Locked, Sophia Publishing House, Bucharest,2005.

[36] Saint Basil the Great, Spiritual Interpretation of the Psalms, trans. Father Dumitru Fecioru, I.B.M.B.O.R. Publishing House, Bucharest, 2006 (see also P.G. 29).

[37] Socrates, Church History, IV, 26, translated by Iosif Gheorghian, Bucharest, 1897.

[38] Sozomen, Church History, VI, 1.5-17, translated by Iosif Gheorghian, Bucharest, 1897.

[39] Theodoret, Bishop of Cyrus, Writings I, part II, Church History, in col. „P.S.B.”, vol. 44, translated by Fr. Prof. Vasile Sibiescu, I.B.M.B.O.R.

[40] The life of the pious Macrina by Saint Gregory of Nice in PG, 46, 959-1000, translated into Romanian by Fr. Prof. Dr. Teodor Bodogae, Sibiu, 1947.

[41] The life of Saint Basil the Great, attributed to his friend (cousin) Saint Amphilochus of Iconia, is a work written in the eighth century in Greek and Latin by F. Combefis, SS. Patrum Amphilochii Iconiensis, Methodii Patarensis et Andreae Cretensis opp., Paris, 1644, 155-225; only in Latin, in PG, 29, CCXCIV-CCCXVI.

[42] Visarion, Bishop, The Old Orders of Monastic Life, Dobrușa-Soroca Monastery, 1929.

[43] Saint Theophanes the Locked, The Orders of Monastic Life, Sophia Publishing House, Bucharest, 2002. 